\title{
Genetic association of variations in the kappa-casein and $\beta$-lactoglobulin genes with milk traits in girolando cattle
}

\author{
Barbosa, Severino Benone Paes ${ }^{1 *}$, Araújo, Ítala Iara Medeiros de ${ }^{1}$, Martins, \\ Marta Fonseca ${ }^{2}$, Silva, Elizabete Cristina da ', Jacopini, Laís Aberrachid ${ }^{1}$, \\ Batista, Ângela Maria Vieira; Silva, Marcus Vinícius Barbosa da ${ }^{2}$
}

Associação genética de variações nos genes da kappa -caseína and $\beta$ lactoglobulina com características do leite de bovinos da raça Gir olando

\author{
${ }^{1}$ Departamento de Zootecnia da Universidade Federal Rural de Pernambuco, Recife-PE, \\ Brasil \\ Embrapa Gado de Leite, Rua Eugênio do Nascimento, uizJ de Fora - MG, Brasil \\ *Correspondence author email: severino.pbarbosa@ufrpe.br
}

\section{SUMMARY}

In dairy farm animals, one the most important goal of the selection is the improvement of milk yield and composition. Several studies have demonstrated that the candidate genes of the kappa-casein (CSN3) and $\beta$ lactoglobulin $(\beta-\mathrm{LG})$ are associated with milk yield, milk quality and health traits in dairy animals. Therefore the aim of this study was to detect polymorphisms in CSN3 and $\beta$-LG genes and its association with milk yield in up to 305 days (305MY) and predicted transmission capacity (PTA) for 305MY in Girolando cattle. Totally, 138 bulls and 729 cows $(n=867)$ were sampled. The genotypes of both genes were obtained by the PCR-RFLP method using HinfI and HaeIII enzymes for $C S N 3$ and $\beta-L G$ genes, respectively. Statistical results revealed two alleles $A$ and $B$ for both genes. The genotypes and alleles more frequents for CSN3 and $\beta-\mathrm{LG}$ genes were respectively:

$A A$ (0.7324) and $A(0.8558)$, and $A B$

$(0.4827)$ and $A(0.5017)$. The $x^{2}$ test revealed that the two loci were at HardyWeinberg equilibrium $(\mathrm{p}<0.001)$. The allele substitution effects for the variants were not significant on 305MY and PTA for 305MY (p>0.05). The allele variants of $\beta-L G$ and
CSN3 might be more investigated before include them into future breeding schemes designed for Girolando dairy cattle with objective of improving milk traits as milk yield in up to 305 days (305MY) and predicted transmission capacity (PTA) for 305MY..

Key words: SNP genotyping, quantitative traits, dairy cattle, milk protein, dairy industry

\section{RESUMO}

Em rebanhos leiteiros, um dos objetivos mais importantes da seleção é a melhoria da produção e composição do leite. Vários estudos demonstraram que os genes candidatos da kappa-caseína (CSN3) e da $\beta$ lactoglobulina $(\beta-L G)$ estão associados à produção de leite, qualidade do leite e características de saúde em animais leiteiros. Portanto, o objetivo deste estudo foi detectar polimorfismos nos genes CSN3 e $\beta-L G$ e avaliar possíveis associações desses polimorfismos com a produção de leite em até 305 dias (305MY) e a capacidade de transmissão prevista (PTA) de leite em bovinos da raça Girolando. No total, 138 touros e 729 vacas $(n=867)$ 
foram amostrados. A genotipagem foi realizada pelo método PCR-RFLP utilizando as enzimas HinfI e HaelII para os genes $C S N 3$ e $\beta-L G$, respectivamente. Os resultados estatísticos revelaram dois alelos A e B para ambos os genes. Os genótipos e alelos mais frequentes para os genes CSN3 e $\beta-L G$ foram respectivamente: AA $(0,7324)$ e $\mathrm{A}(0,8558)$ e $\mathrm{AB}(0,4827)$ e $\mathrm{A}$ $(0,5017)$. O teste $x^{2}$ revelou que os dois loci estavam em equilíbrio de Hardy-Weinberg ( $p<0,001)$. Os efeitos de substituição alélica para as variantes não foram significativos para as características 305 MY e PTA para 305MY (p>0,05). Portanto, as variantes alélicas identificadas nos genes $\beta$ - $L G$ e $C S N 3$ devem ser mais investigadas antes de serem incluídas nos programas de melhoramento desenhados para bovinos leiteiros Girolando objetivando melhorar as características do leite analisadas no presente estudo.

Palavras-chave: genotipagem de SNP, características quantitativas, bovinos leiteiros, proteína do leite, indústria leiteira 


\section{INTRODUCTION}

The Girolando breed is one of the most important breeds of dairy cattle in Brazil, resulting from the crossing between Gyr (a Bos indicus breed) and Holstein (a Bos taurus breed) cattle breeds, since 1/2 Holstein $+1 / 2 \mathrm{Gyr}$ until 13/16 Holstein + 3/16 Gyr, and has shown better adaptation to hot temperatures and tropical diseases (Facó et al., 2005; Bicalho et al., 2006). The purpose of the formation of the Girolando breed is to obtain animals of $5 / 8$ composition Holstein $+3 / 8 \mathrm{Gyr}$ with well-defined racial pattern and good dairy productivity (SILVA et al., 2016). This breed was selected for several years for increasing milk produced in the country.

Polymorphisms in candidate genes related to economically important traits in dairy cattle such as the candidate genes of kappa-casein (CSN3) and betalactoglobulin $(\beta-L G)$ have been associated with milk composition, cheese production, milk quality and milk production (Botaro et al., 2009; Stipp et al., 2013; Singh et al., 2014; Selvaggi et al., 2014).

Beta-lactoglobulina protein represents about $50 \%$ of total whey protein of ruminant milk (Fox \& McSweenwey, 1998; Selvaggi et al. 2014). Milk $\beta$ - $L G$ gene was mapped to chromosome 11 in bovine and molecular studies already determined 15 alleles in this gene (Matejicek et al., 2008), out of which A e B variants are the most frequent and investigated (Zaglool et al., 2016). In bovines, the variant $\mathrm{B}$ has been more related to milk quality while variant $\mathrm{A}$ has been more associated with milk yield (Ng-Kwai-Hang et al. 2002; Tsiaras et al., 2005).

Caseins are milk proteins secreted by mammary gland cells, constitute about $78-82 \%$ of bovine milk proteins and are divided into four different types of caseins: alpha s1, alpha s2, beta, and kappa, where approximately $12 \%$ contribution comes from кappa-casein. Eleven variants have been reported for CSN3 (Prinzenberg et al., 2008; Caroli et al., 2009, Botaro et al., 2009) associated with composition, processing, milk quality and milk yield, being A and B the most frequent (Sitkowska et al., 2009; Dogru \& Ozdemir, 2009; Ju et al., 2009). The A allele is favorable to milk yield, but with lower protein content, while B allele is related to higher fat and protein contents, but with lower milk yield (Botaro et al., 2009; Ju et al., 2009; Hamza et al., 2010).

Within this context, this present study aimed to identify $\mathrm{A}$ and $\mathrm{B}$ allele variants of $C S N 3$ and $\beta-L G$ genes and to investigate whether its association with milk yield in up to 305 days (305MY) and predicted transmission capacity (PTA) for $305 \mathrm{MY}$ to develop tools for the selection of animals participating in a test of progeny of the Girolando breed in Brazil. .

\section{MATERIAL AND METHODS}

To detect polymorphisms in the CSN3 and $\beta-L G$ bovine genes, samples of semen and or blood were collected from 867 unrelated animals (138 bulls and 729 cows) from different contemporary groups that participate of the Girolando Progeny Test coordinated by the Breeders Association of the Girolando Breed in partnership with Embrapa Dairy Cattle-National Dairy Cattle Research Center. The biological material used in this research represents all samples available in the DNA Bank at Embrapa until March 2012. These samples were collected during the milk control or linear classification of the 
animals. All animals used in this study came from different private farms that participate of the Progeny Test and were a representative population of a population studied by SILVA et al. (2012).

The genomic DNA samples were extracted from blood and semen cells using a Dneasy Blood \& Tissue Kit (Qiagen, Hilden, Germany), according to the manufacturer's recommendations. Subsequently, the quality of DNA genomic DNA including concentration and purity was verified using a Spectrophotometry (Nanodrop 1000, Thermo Fisher Scientific Inc., Wilmington, USA). After that, the extracted DNA samples were submitted to the PCR amplification technique (Polymerase Chain reaction), using the oligonucleotides initiators (primers) described by Barroso et al. (1998) and Medrano and Aguilar-Cordova (1990) for the CSN3 and $\beta-L G$ genes, respectively (Table 1$)$.

Table 1. Sequences of the forward $(F)$ and reverse $(R)$ primers for the amplification of the kappa-casein (CSN3) and $\beta$-Lactoglobulin $(\beta$-LG) genes.

\begin{tabular}{lll}
\hline Genes & \multicolumn{1}{c}{ Primers sequences $\left(5^{\prime} \rightarrow 3^{\prime}\right)$} & \multicolumn{1}{c}{ Reference } \\
\hline$C S N 3$ & F-TGTGCTGAGTAGGTATCCTAGTTATGG & Barroso et. (1998) \\
$\beta-L G$ & R-GCGTTGTCTTCTTTGATGTCTCCTTAG & \\
& F-GTCCTTCTGCTGACACCGACTACA & $\begin{array}{l}\text { Medrano \& } \\
\text { R-CAGGACACCGGCTCCCGGTATATGA }\end{array}$ \\
& & $\begin{array}{l}\text { Aguilar-Cordova } \\
(1990)\end{array}$ \\
\hline
\end{tabular}

PCR amplification was prepared in a 25 $\mu \mathrm{l}$ volume containing of $400 \mathrm{nM}$ and $125 \mathrm{nM}$ of each primer, for the CSN3 and $\beta$-LG genes respectively; $50 \mathrm{ng}$ of genomic DNA and 1x from GoTaq Green Master Mix (Promega, Madison,

Wisconsin, USA). The gene amplification programs consisted: $94^{\circ} \mathrm{C}$ for $5 \mathrm{~min}, 35$ cycles $\left(94{ }^{\circ} \mathrm{c}\right.$ for $1 \mathrm{~min} ; 65$ ${ }^{\circ} \mathrm{c}$ for $1 \mathrm{~min}\left(60{ }^{\circ} \mathrm{c}\right.$ for $\left.\beta-\mathrm{LG}\right) ; 72{ }^{\circ} \mathrm{c}$ for $1 \mathrm{~min}$ ) followed by a final extension for $5 \mathrm{~min}$ at $72{ }^{\circ} \mathrm{c}(7 \mathrm{~min}$ for $\beta-\mathrm{LG})$. For amplification, the cycler GeneAmp PCR System 9700 (Applied Biosytem, Forster City, CA, USA) was used. The restriction digestion of the PCR products was carried out with the HinfI and HaeIII enzymes (New England Biolabs, Inc., Ipswich, USA) according to manufacturers' recommendations. The digestion products were analyzed on $2 \%$ agarose gel.

Allelic and genotypic frequencies were calculate to determine the population structure by using Popgen version 1.32 package (Yeh et al., 1997), and the significance of differences between observed and expected genotype frequencies was tested based on Chisquare $\left(\chi^{2}\right)$ test at one degree of freedom at one percent level to test whether the distribution of the genotypic frequencies was in the Hardy-Weinberg equilibrium.

For the association study, milk production data in up to 305 days $(305 \mathrm{MY})$ of 536 cows were used. For the Predicted Transmitting Ability (PTA) for 305MYdata, information from 127 bulls and 536 cows were included.

The group of evaluated sires presented genetic composition of $3 / 4$ and $5 / 8$ of Holstein breed and the group of cows presented the genetic composition equal to or greater than $5 / 8$ of the Holstein 
breed.

substitution model:

Estimates of PTA for 305MY

were calculated using an allelic

$$
Y i j=\mu+S i+\beta x i j+\varepsilon i j
$$

where,

Yij is the relative value of the PTA for $305 \mathrm{MY}$ daughter $\mathrm{j}$ of sire $\mathrm{i}, \mu$ is the overall population mean, $\mathrm{Si}$ is the fixed effect of sire $i, \beta$ is the regression coefficient representing one-half the allele substitution effect $(\alpha / 2)$, xij is the number of $B$ alleles $(0,1$ or 2$)$ for the $j$ daughter of sire i, and eij is the residual.

Estimates of PTA for 305MY were weighted by accuracy values to obtain weighted least squares estimates for the allele substitution effects. Data of P305 were analyzed following fixed effects model:

$$
\text { Yijklm }=\mu+\mathrm{Sj}+\mathrm{GCk}+\mathrm{CGl}+\mathrm{Om}+\text { eijklm, }
$$

where,

Yijklm represent the milk production of cow $i$, daughter of sire $j, \mu$ is a general constant, $\mathrm{Sj}$ is the fixed effect of $\mathrm{j}$ th sire, GCk is the fixed effect of $\mathrm{k} t h$ contemporary group $(\mathrm{k}=1,2, \ldots, 52)$ (herds, calving birth and calving season); CGl is the fixed effect of $1 t h$ genetic composition $(1=1,2,3,4,5,6$, these are representing the genetic composition of Girolando animals), Om is the effect of $\mathrm{m} t h$ genotype $(\mathrm{m}=\mathrm{AA}$, $\mathrm{AB}, \mathrm{BB})$ and eijklm is the residual.

The association study was carried out through regression analysis, using the GLM procedure of SAS 9.1 (SAS Institute, Inc., Cary).

\section{RESULTS AND DISCUSSION}

The use of the molecular PCR-RFLP technic chose in this study was effective to detect kappa-casein (CSN3) and beta- lactoglobulin $(\beta-L G)$ polymorphisms. The CSN3 gene amplification product produced a DNA fragment of $453 \mathrm{bp}$ that was digested with HinfI restriction enzyme, and for types of restriction patterns were obtained 426, 326, 100 and $27 \mathrm{bp}$ as shown in Figure 1. The AA genotype was identified by the presence of three fragments $(-326,100$ and $27 \mathrm{bp})$, the $A B$ is characterized by the presence of the four fragments $(-426,326,100$ and 27 bp) and the BB has only two fragments (426 and $27 \mathrm{bp}$ ).

For the $\beta$ - $L G$ gene, a 262 bp fragment was amplified with two polymorphic alleles represented by four 153, 109, 79 and $74 \mathrm{bp}$ fragments from the enzymatic digestion of the PCR product with HaeIII (Figure 2). The AA genotype identified by the presence of two fragments (-153 and $109 \mathrm{bp}), \mathrm{AB}$ is characterized by the presence of the four fragments $(-153,109,79$ and 74) and the BB has three fragments $(-109$, 79 and $74 \mathrm{bp}$ ). 


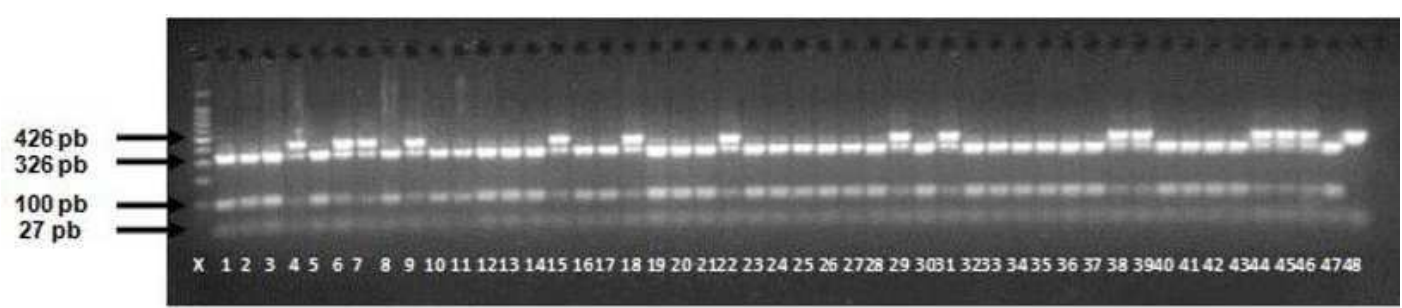

Figure 1. Gel electrophoresis of CSN3-Hinf I/PCR-RFLP fragments. Lane X100bp of DNA Ladder; lanes 1-3, 5, 8, 10-14, 16, 17, 19-21, 23-28, 30, 32-37, 40-43, 46 and 47 represent the genotype AA; lanes 4, 6, $7,9,15,18,22,29,31,38,39,44$ and 45 represent the $\mathrm{AB}$ genotype; lane 48 represent the BB.

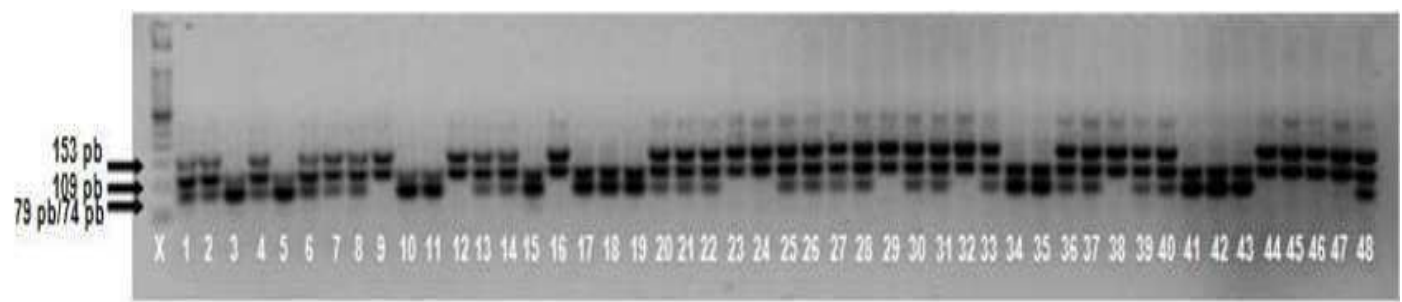

Figure 2. Gel electrophoresis of $\beta$-LG-HaeIII/PCR-RFLP fragments. Lane X100bp of DNA Ladder; lanes 9, 12, 16, 23, 24, 29, 32, 38 and 44-47 represent the AA genotype; Lanes 1, 2, 4, 6-8, 13, 14, 20-22, 25-28, $30,31,33,36,37,39,40$ and 48 represent the $\mathrm{AB}$ genotype; Lanes 3, $5,10,11,15,17-19,34,35$ and $41-43$ respresent $\mathrm{BB}$ genotype.

Knowledge about the proportions of the different genotypes and the different alleles of the candidate genes in the population through the study of the genotype and allelic frequencies and the association of these with the productive records of the animals may allow the development of strategies for marker assisted selection (MAS), making it possible to increase milk production and improve physical-chemical and technological characteristics, as well as increasing the speed and dynamism in the decision making regarding the selection or culling of animals for reproduction. According to Drogemuller et al. (2001) the use of MAS together with traditional selection tools can be more effective when the aim of breeding program is improving complex traits because with the MAS is possible getting faster genetic progress.
The genotypic and allelic frequencies for the CSN3 and $\beta-L G$ genes are summarized in Table 2 . The frequencies of alleles A and B at locus CSN3- Hinf $I$, were 0.86 and 0.14 , with resulting in AA genotype being the most frequent (0.73). For $\beta$-LG gene, allelic frequency of $\mathrm{A}$ and $\mathrm{B}$ variants has been more close $\mathrm{A}=0.52$ and $\mathrm{B}=0.48$. The $\mathrm{AB}$ genotype from $\beta-L G$ occurred at higher frequency demonstrating there was more variability in this gene in Girolando cattle analyzed in this study. The probability of deviations from the Hardy-Weinberg expectations for both genes were based on Chi-square test $(\chi 2)$ and showed that all genotypic frequencies in the population were in Hardy-Weinberg equilibrium $(\mathrm{P}<0.01)$ (Table 2).

Based on the results of this study, obtained for the CSN3 gene, was 
observed a tendency for the fixation of higher AA genotype frequency in this population, corroborating with other studies showing this similar results for the zebu breeds, such as Gir (Silva \& Del Lama, 1997; Kemenes et al., 1999) and taurine, such as the Holstein ( $\mathrm{Ng}$ Kwai-Hang et al., 1984; Lin et al., 1986; Hallen et al. 2011; DuifhuisRivera et al., 2014). The low frequency of the B allele, which was reported in previous studies to be associated with higher yield for cheese production, was expected because the frequency of this allele in both founding breeds (Holstein and Gir) of Girolando is also low (Famula \& Medrano, 1994; Tsiaras et al., 2005; Azevedo et al., 2008).

The allele frequencies found for the $\beta$ $L G$ gene differ from those obtained by Ng-Kwai-Hang et al. (1984), who the A allele, and it has contributed to studied the genotypic and allelic frequencies of 3,870 Holstein cows reared in 63 commercial herd in Quebec and they did not find the alleles equally distributed in the studied population with allelic frequencies of 0.39 and 0.61 for $\mathrm{A}$ and $\mathrm{B}$, respectively, and frequencies genotypic of 0.1334 (AA), $0.5054(\mathrm{AB})$ and $0.3602(\mathrm{BB})$. The population studied by these authors was also in EHW and the proportion of heterozygous individuals was higher than that of homozygotes, as verified in the present study. On the other hand, Botaro (2007) obtained, using 74 Girolando animals in his study, greater frequency of genotype $\mathrm{BB}(0.45)$ than genotypes $\mathrm{AB}$ (0.34) and AA (0.21), finding no balance in the population.

Table 2. Allelic and genotypic frequencies for $C S N 3$ and $\beta-L G$ genes in Girolando cattle.

\begin{tabular}{|c|c|c|c|c|c|c|}
\hline \multirow[t]{2}{*}{ Loci } & \multirow[t]{2}{*}{ Genotypes } & \multicolumn{2}{|c|}{$\mathrm{N}^{\mathrm{o}}$ of genotype } & \multicolumn{2}{|c|}{ Frequency } & \multirow{2}{*}{ EHW $\left(x^{2}\right)$} \\
\hline & & Observed & Expected & Genotypic & Allelic & \\
\hline
\end{tabular}

CSN3-Hinf I

$\begin{array}{llllll}\text { AA } & 635 & 635.02 & 0.73 & 0.86(\mathrm{~A}) & \\ \text { AB } & 214 & 213.96 & 0.25 & & 0.00 * * \\ \text { BB } & 18 & 18.02 & 0.021 & 0.14(\mathrm{~B}) & \end{array}$

$\beta$-LG-HaeIII

$\begin{array}{llllll}\text { AA } & 226 & 218.50 & 0.26 & 0.52(\mathrm{~A}) & \\ \text { AB } & 419 & 433.99 & 0.48 & & 1.04 * * \\ \text { BB } & 223 & 215.50 & 0.26 & 0.48(\mathrm{~B}) & \end{array}$

$* * \mathrm{P}<0.01$

In the present study was no significant association ( $>0.05)$ between the different genotypes and milk yield in up to 305 days (305MY) and predicted transmission capacity (PTA) for 305MY of Girolando cows and bulls analyzed. The average of the analyzed traits for the observed allelic substitution $(\alpha / 2)$ for $C S N 3$ and $\beta-L G$ genes are shown in Table 3.

The non-significance of the association of the variables with allele variants also resembles those obtained by previous studies with Holstein cows (Aleandri et al., 1990; Ng-Kwai-Hang et al., 1990; Tsiaras et al., 2005). The current results 
regarding the relationship between milk production and $B$ allele are in agreement with those obtained by Bovenhuis et al. (1992), who genotyped 6,803 Holstein cows for the CSN3 gene and determined that the $\mathrm{BB}$ genotype produced lower amounts of milk compared to AA cows, although for these authors the results were significant. The results of Rachagani \& Gupta (2008) indicated that genotype $\mathrm{BB}$ produced more milk than those of genotypes $\mathrm{AA}$ and $\mathrm{AB}$, also a significant study.

The conflicting results found in the literature for CSN3 showed that the A allele (Gonyon et al., 1987; Bovenhuis et al., 1992), or the B allele (Lin et al., 1986, 1989, Eenennaam \& Medrano, 1991) are being related to higher milk production. According to Ng-Kwai-
Hang et al. (1990), this fact can be attributed to the different number of samples analyzed, different genetic material and mainly to the rigor of the statistical analyzes.

Considering that all variants of the CSN3 gene are located on region of chromosome 6 , between 200 and 300 $\mathrm{kb}$, potentially the proximity of the genes, for the effect of binding disequilibrium is great. However, this effect within a family can be altered due to differences between casein loci and other protein genes, which could explain the inconsistencies observed in previous studies (Cowan et al., 1992; Braunschweig et al., 2000). In addition, kappa-casein and beta-casein have been showed a strong link between the effects of gene binding (Bovenhuis et al., 1992).

Table 3. Estimates of allelic substitution $(\alpha / 2)$ and $p$-value associated with $C S N 3$ and $\beta$ $L G$ in cows and bulls Girolando population.

\begin{tabular}{lcccc}
\hline \multirow{2}{*}{ Variables } & \multicolumn{2}{c}{ CSN3 } & \multicolumn{2}{c}{$\beta$-LG } \\
& $\begin{array}{c}\text { Allelic } \\
\text { substitution }(\alpha / 2)\end{array}$ & p-value & $\begin{array}{c}\text { Allelic } \\
\text { substitution }(\alpha / 2)\end{array}$ & $p$-value \\
\hline 305MY $(\mathrm{kg})$ & -62.93 & 0.6924 & -34.98 & 0.7846 \\
PTA for 305MY $(\mathrm{kg})$ & -14.16 & 0.6179 & -18.39 & 0.4130 \\
\hline
\end{tabular}

The results found in this study resemble those obtained by Ng-Kwai-Hang et al. (1990), with animals of the Holstein breed that also did not find significant effect for the association of the $\beta-L G$ gene with milk production. However, Aleandri et al. (1990) observed that AA genotype determined higher milk yield in first-lactating Holstein cows, as well as Bovenhuis et al. (1992) who observed that AA Hollander cows produced $93 \mathrm{~kg}$ more milk than cows of genotype $\mathrm{BB}$. This result is not in agreement with Jairam \& Nair (1983) that demonstrated higher milk yield for cows with $\mathrm{BB}$ genotype.

In addition the $A$ allele for $C S N 3$ was the major allele and it may suggest that this enzymatic site was less informative to detect variability in Girolando cattle. Therefore, the allele variants of $\beta-L G$ and CSN3 might be more investigated before include them into future breeding schemes designed for Girolando dairy cattle with objective of improving milk traits as milk yield in up to 305 days (MY305) and predicted transmission capacity (PTA) for 305MY. 


\section{REFERENCES}

ALEANDRI, R; BUTTAZZONI, L. G.; SCHNEIDER, J.C.; CAROLI, A.; DAVOLI, R. The effects of milk polymorphism on milk components and cheese producing ability. Journal of Dairy Science, v.73, p. 241-255. 1990 AZEVEDO, A.L.S.; NASCIMENTO, C.S.; STEINBERG, R.S.; CARVALHO, M.R.; PEIXOTO, M.G.; TEODORO, R.L.; VERNEQUE, R.S.; GUIMARÃES, S.E.; MACHADO, M.A. Genetic polymorphism of the kappa-casein gene in Brazilian cattle.

Genetic Molecular Research, v.7, n.3, p. 623-630, 2008.

BARROSO, A., DUNNER, S.; CAÑON, J. Technical note: detection of bovine kappa-casein variants A, B, $\mathrm{C}$ and $\mathrm{E}$ by means of Polymerase Chain Reaction-Single Strand Conformation Polymorphism (PCRSSCP). Journal Animal Science, v.76, p.1535-1538, 1998.

BICALHO, H.M.S.; PIMENTA, C.G; MENDES, I.K.P.; PENA, H.B.; QUEIROZ, E.M.; PENA, S.D.J. Determination of ancestral proportions in synthetic bovine breeds using commonly employed microsatellite markers, Genetic Molecular Research, v.5, n.3, p. 432-437, 2006.

BOTARO, B.G.; LIMA, Y. V. R.; CORTINHAS, C.S.; PRADA, L. F.; SILVA, F. P. RENNÓ; SANTOS, M. V dos. Effect of the kappa-casein gene polymorphism, breed and seasonality on physicochemical characteristics, composition and stability of bovine milk. Revista Brasileira de Zootecnia, v.38, n.12, p. 2447-2454, 2009.

BOVENHUIS, H.; ARENDONK, J.A.M.; KORVER, S. Association between milk protein polymorphisms and milk production traits, Journal of Dairy Science, v.75, n.9, p. 2549, 1992. BRAUNSCHWEIG, M.; HAGGER, C.; G. STRANZINGER. Association between casein haplotypes and milk production traits of swiss brown cattle. Journal Dairy Science, v.83, n.6, p.1387-1395, 2000.

CAROLI, A.M., CHESSA, S.; ERHARDT, G.J. Milk protein polymorphisms in cattle: effect on animal breeding and human nutrition. Journal of Dairy Science, v.92, n.11, p.5335-5352, 2009.

COWAN, C. M.; DENTINE, M.R.; COYLE, T. Chromosome substitution effects associated with $\mathrm{k}$-casein and $\beta$ lactoglobulin in Holtein cattle. J. Dairy Sci. 75: 1097-1104, 1992.

DOGRU, U.; OZDEMIR M.

Genotyping of Kappa-Casein Locus by PCR-RFLP in Brown Swiss Cattle Breed, Journal of Animal and Veterinary Advance, v.8, p.779-781, 2009.

DROGEMULLER, C.; HAMANN, H.; DISTL, O. Candidate gene markers for litter size in different German pig lines, Journal of Animal Science, v.79, p. 2565-2570, 2001.

DUIFHUIS-RIVERA, T., C.; LEMUS-FLORES, M. Á.; AYALAVALDOVINOS, D. R.; SÁNCHEZ CHIPRÉS, J.; GALINDO-GARCÍA, K.; MEJÍA-MARTÍNEZ; E. GONZÁLEZ-COVARRUBIAS.

Polymorphisms in beta and kappa-casein are not associated with milk production in two highly technified populations of holstein cattle in mexico. The Journal of Animal Plant and Science, v. 24, n.5, p.1316-1321, 2014. 
EENENNAAM, A.V.; MEDRANO, J.F. (1991). Milk protein polymorphisms in California dairy cattle. Journal Dairy of Science, v.74, n.5, p.1730-1742.

EMMONS, D.B.; DUBE, C.; MODLER, H.W. Transfer of protein from milk to cheese. Journal of Dairy Science, v.86, n.2, p.469-485, 2003.

FACÓ, O.; LÔBO, R. N. B.; MARTINS FILHO, R.; LIMA, F. A. M. Idade ao primeiro parto e intervalo de partos de cinco grupos genéticos Holandês x Gir no Brasil. Revista Brasileira

Zootecnia, v.34, n.6, 2005.

FAMULA, T.R.; MEDRANO, J.F. Estimation of genotype effects for milk proteins with animal and sire transmitting ability models, Journal of Dairy Science, v.77, p.3153-3162, 1994.

FOX, P.F.; P.L.H. McSWEENWLY. Dairy chemistry and biochemistry. London: Blackie Acad. \& Prof., p. 478, 1998.

GONYON, D. S.; MATHER, R. E.; HINES, H.C. Association of bovine blood and milk polymorphisms with lactation traits: Holteins. Journal of Dairy Science, v.70, p.2585-2598, 1987.

HAMZA, A.E.; YANG, Z.P.; WANG, X.L.; CHEN, R.J.; WU, H.T.;

IBRAHIM, A.I. The Impact of Kappa Casein Gene Polymorphism on Milk Components and Other Productive Performance Traits of Chinese Holstein Cattle. Pakistan Veterinary Journal, v.31, n.2, p.153-156, 2010.

JAIRAM, B. T.; NAIR, P.G. Genetic polymorphisms of milk proteins and economic characters in dairy animals. Indian Journal of Animal Science, v. 53, n.1, 1983.

JU, Z.; LI, Q.; WANG, H. J.; LI, O.; YANG, W.; ZHONG, J.; CHANG, F.W. (2009). Polymorphisms of $\kappa$-casein gene exon4 and exon 5 and its Association with milk production traits in Chinese Holsteins cattle. Scientia Agricultura Sinica, v.9, p.3279-87.

KEMENES, P. A.; REGITANO, L. C. A.; ROSA, A. J.; PACKER, M. I. U.; RAZOOK, A. G.; FIGUEIREDO, L. A.; SILVA, N. A.; ETCHEGARAY, M. A. L.; COUTINHO, L.L. k-Casein, blactoglobulin and growth hormone allele frequencies and genetic distances in Nelore, Gyr, Guzerá, Caracu, Charolais, Canchim and Santa Gertrudis cattle. Genetic Molecular Biology, v. 22, n.4, p. 539-541, 1990.

LIN, C. Y.; MCALLISTER, K.F.; NGKWAIHANG, K.F. Effects of milk protein loci on first lactation production in dairy cattle, Journal of Dairy Science, v.69, p.704 -712, 1986.

LIN, C. Y.; McALLISTER, K.F.; NGKWAIHANG, K. F. Relationships of milk protein types to lifetime performance, Journal of Dairy Science, p.72: 3085 - 3090, 1989.

MATEJICEK, A.; MATEJICKOVA, J.; STIPKOVA, M. Joint effects of CSN3 and LGB genes on milk quality and coagulation properties in Czech Fleckvieh. Czech Academy of Agriculture and Sciences, v. 53, n.6, p. 246-252, 2008.

MEDRANO, J.F.; AGUILARCORDOVA, E. Polymerase chain reaction amplification of bovine Blactoglobulin genomic sequences and 
identification of genetic variants by RFLP analysis. Animal

Biotechnology, v.1, n.1, p.73-77, 1990.

NG-KWAI-HANG, K.F.; MONARDES, H.G.; HAYES, J.F. Association between genetic polymorphism of milk proteins and production traits during three lactations. Journal of Dairy Science, v.73, p. 3414-3420, 1990.

NG-KWAIN-HANG, K. F.; HAYES, J.F.; MOXLEY, J.E. Association of genetic variants of casein and milk serum proteins with milk, fat, and protein production by dairy cattle. Journal of Dairy Science, v.67, p. 835-840, 1984.

NG-KWAI-HANG, K.F.; OTTER, D. E.; LOWE, E.; BOLAND, M.J.; AULDIST, M. J. Influence of genetic variants of beta-lactoglobulin on milk composition and size of casein micelles. Milch. v.57, n.6, p.303-306, 2002.

PRINZENBERG, E.M.; JIANLIN, H.; ERHARDT, G. Genetic variation in the K-casein gene (CSN3) of Chinese Yak (Bos grunniens) and phylogenetic analysis of CSN3 sequences in the genus Bos. Journal of Dairy Science, v. 91, n.3, p.1198-1203, 2008.

SELVAGGI, M.; LAUDADIO, V.; DARIO, C.; TUFARELLI, V.

Investigating the genetic polymorphism of sheep milk proteins: a useful tool for dairy production. Journal of Science

Food Agriculture, v. 94, v.15; p. 3090-3099, 2014.

SILVA, I. T.; DEL LAMA, M.A. Milk protein polymorphism in Brazilian Zebu cattle. Brazilian Journal of Genetics, v. 20, n.4, p. 625 - 630, 1997.

SILVA, M. V. G. B. ; MARTINS, M. F. ;
PAIVA, L. C. ; CEMBRANELLI, M. A. R. ; FREITAS, A. F. ; ARBEX, W. A. ; SANTOS, K. C. L. ; CAYO, A. W. C. ; PANETTO, J. C. C. ; COSTA, C. N. ; CARVALHO, B. C. ; FERREIRA, M. B. D. ; LOPES, B. C. Programa de Melhoramento Genético da Raça Girolando. Sumário de Touros. Resultado do Teste de ProgênieJunho/2012. Juiz de Fora: Embrapa Gado de Leite, 2013 (Documentos, 154).

SILVA, M. V. G. B.; MARTINS, M. F. ; CEMBRANELLI, M. A. R. ; PANETTO, J. C. C.; FREITAS, A. F.; PAIVA, L. C. Programa de Melhoramento Genético da Raça Girolando - Avaliação Genética de Vacas - Junho/2016. Juiz de Fora : Embrapa Gado de Leite, 2016. 40 p. (Documentos, 192).

SINGH, U.; DEB, R.; KUMAR, S.; SINGH, R.; SENGAR, G.; SHARMA, A. Association of prolactin and betalactoglobulin genes with milk production traits and somatic cell count among Indian Frieswal (HF $\times$ Sahiwal) cows. Biomarkers and Genomic Medicine, v. 7, n.1, p.38-42, 2014.

STIPP, A.T.; BIGNARDI, P.R.; POLIFREDERICO, R.C.; SIVIERI, K.; COSTA, M.K. Polimorfismos genéticos da kappa-caseína e da betalactoglobulina e produção de leite em bovinos. Arquivo Brasileiro de Medicina Veterinária e Zootecnia, v.65, n.1, p.275-280, 2013.

TSIARAS, A.M.; BARGOULI, G.G.; BANOS, G.; BOSCOS, C.M. Effect of kappa-casein and beta-lactoglobulin loci on milk production traits and reproductive performance of Holstein cows, Journal Dairy Science, 88: 327334, 2005. 
YEH, F.C.; YANG, R.C.; BOYLE,

T.B.J. Popgene (VERSION 1.32):

Software Microsoft Windows-based freeware for population genetics analysis. Alberta: University of Alberta, 1997.

ZAGLOOL, A.W.; AWAD, A.; EL, S.; EL, A.; EL-BAYOM, K.M.. Association of $\beta$-Lactoglobulin Gene Polymorphism with Milk Yield, Fat and Protein in Holstein-Friesian Cattle. World. v.6, n.3, p. 117-122, 2016. 